\title{
The Higher Education System in Argentina. Networks, Genealogies and Conflicts
}

\author{
Andrés Santos Sharpe \\ CONICET-Instituto de Investigaciones Gino Germani (Gino Germany Research Institute), Social Science \\ Faculty/University of Buenos Aires, Buenos Aires, Argentina \\ Email: andres iss@yahoo.com.ar
}

Received 5 August 2015; accepted 26 October 2015; published 29 October 2015

Copyright (C) 2015 by author and Scientific Research Publishing Inc.

This work is licensed under the Creative Commons Attribution International License (CC BY).

http://creativecommons.org/licenses/by/4.0/

(c) (i) Open Access

\begin{abstract}
The present manuscript aims to identify the genealogies, understood in a Foucaultian perspective, which leads to the actual Higher Education System in Argentina, by distinguishing how series of events are organized, distributed, organized in terms of institutional relations, signifying chains in the social amalgam and educational networks. This analysis will allow understanding the hierarchical relationships between higher education institutions and how the differences on cultural and curricular traditions and history also motivate (though not impose) the differences on the students and on policies. Finally, it is as well an accurate description of the Higher Education System in Argentina with a strong emphasis on universities.
\end{abstract}

\section{Keywords}

\section{Higher Education, Argentina, Educational Policies}

\section{Introduction}

Studies in higher education began to take shape as a field of studies in Argentina from 1995 onwards; if a foundational milestone should be established, that would be the opening of the seminars "La Universidad como objeto de investigación” [“The university as a research object”] that began that year (Carli, 2012: p. 13).

While prior to the 2001 crisis, it could not be said that there was a strictly delimited field, mainly because of "the absence of rules that structure the conflict, responsibilities and positions on the different legitimate ways of producing knowledge in this level of the education system” (own translation, Krotsch \& Suasnábar, 2002), we can still find some recurrent topics in studies on higher education; the most important being related to changes in university policies, globalization in higher education and, regarding students, the student movement as a leading actor (Carli, 2012). 
Since the beginning of the new millennium, scientific production related to studies in higher education in Argentina began to multiply and connect with other knowledge areas. Due to the constant dynamism in this field, previous reports that depict the Argentinean University Educational System (SEU, by its Spanish acronym) are now outdated, which hinders the possibility of establishing relationships and comparisons with other countries' higher education systems.

For this reason, the following work aims to present a brief description of the SEU in Argentina, primarily focusing on the present time, as well as including some of the historical references that provided the background for the development of the SEU, in order to be used as a reference by other researchers and academics to understand the logic and conflicts, and to develop links between different university systems in each country.

In order to accomplish this goal, it is necessary to lay emphasis on some distinctions: the Higher Education System in Argentina (SES, by its Spanish acronym) is comprised of a wide range of institutions which for this purpose, it has been categorized into two major analytically organized subsystems. The main differences between these two subsystems arise from their differentiated foundation processes, institutional and disciplinary traditions, tied with the Argentinean social structure, and the way the elites reproduce themselves-the elites as well as certain groups which exercise a defined power within the subsystems and operate conditioning and organizing them in coordination with networks of social relationships that are diversely intertwined in each of these subsystems. Furthermore, the contrast between the higher education subsystems can be seen in the various administrative and governing bodies in the educational field, among other elements that influence their institutional life, from which these subsystems are shaped and organized by different State areas and regulated by different laws.

Therefore, on the one hand there is a subsystem which encompasses universities and university institutes (SEU), while on the other hand there is a second subsystem comprising Higher Education Institutes which are divided into teacher training and technical-vocational (SIES, by its Spanish acronym). This piece of work will focus on the first of these two groups, the Educational University System (SEU). However, in order to strengthen the understanding of this subsystem in its specificity, the contrasts with the second of these groups-which will be called System of Higher Education Institutes (SIES)—will as well be included.

Considering these aspects, the first section will summarize the differences between the SIES and the SEU with regard to areas of action (both State and market related), institutional traditions, characteristics of the sectors attending and their various mechanisms of reproduction of the elites; in conjunction with the laws that regulate each subsystem and their relationship with different State levels and external agencies, resulting from specific historical conditions of emergence.

From the second section, this work will focus on the Argentine SEU bearing in mind the historical context of emergence of the different types of universities, so that a typology of the different groups of universities can be made in order to discriminate their institutional traditions and respective cultures. Furthermore, significant historical events from which these institutional cultures stem from will be inspected.

Finally, the last section will refer to some current affairs and debates regarding the SEU, in relation with its link with the State and the labor market, as well as difficulties and dilemmas within the very system.

\section{The Argentine Higher Education System (SES): Two Subsystems}

As mentioned in the introduction, two distinct sets of educational institutions exist within the SES: one comprising universities and university institutes (SEU), which focuses on the training of specialized professionals, scientists, and academics; and another group comprising higher education institutes (SIES), dedicated to technical-vocational and teacher training.

Although both subsystems are a part of the higher education field in Argentina, they do not share common origins with regard to history and production conditions. As a result, each subsystem's relationship with the State is different, and so are the characteristics of their communities (teachers as well as students, in relation to social, economic, and cultural sectors of origin) and their institutional culture.

Both teacher training colleges and technical institutes belonging to SIES developed closely associated with the middle-level education system. In Argentina, teacher training and technical schools emerged as isolated projects that later on were replicated, especially in the case of "Escuelas Normales" (teacher training secondary schools). However, when law No. 1420 was enacted in 1884 (this law stipulates that education shall be secular,

\footnotetext{
““Escuelas Normales” was the designation for teacher training colleges prior to the tertiarization process (i.e., it’s conversion into a tertiary level of education).
} 
compulsory and free of charge) and the National Board of Education created in 1881, it began a considerable promotion of the "Escuelas Normales" in order to give way to the institutionalization of the educational system. Thus, very high levels of steady growth for that area and time ${ }^{2}$ were achieved; by the '20s, 95 middle schools had been built — a sum to which 37 private institutions controlled by a State middle school could be added. It is estimated that by 1930 middle schools had issued a total of 50,000 diplomas (Fiorucci, 2014: p. 26).

On the other hand, the development of technical schools began later and it was a less uniform system. The official availability of institutions for technical training was comprised of four different types of institutions (Dussel \& Pineau, 1995: p. 113) ${ }^{3}$, all of which had different admission requirements. Nonetheless, in Argentina the process of homogenizing technical schools began firstly after the first incipient industrialization process during the ' $30 \mathrm{~s}^{4}$, and secondly during the first Peronist mandate, which introduced active policies towards professional technical education (Dussel \& Pineau, 1995).

Nonetheless, despite which the first institutions of this type were, the focal point is that both teacher training and technical-vocational training provided different options for secondary education. That is to say, once students had finished elementary school they could choose between different types of education, if they wanted to and could afford it: a more traditional humanistic High School (Bachiller), the most common; Business School (Comercial), for those who wanted to work in public and private administration; Technical or Industrial School (Técnico o Industrial); and teacher training School (Escuela Normal).

In summary, the current Higher Education Institutes of the SIES were an option within secondary education until Resolution No. 2321/70, enacted in October 2, 1970 during Onganía’s dictatorship. After the resolution, these institutes were transferred to the Higher Education area in a process called tertiarization (that is to say, the conversion of these institutes into a higher-level education outside universities) and their management and administration was given to the provinces (Southwell \& De Luca, 2008). The transference of jurisdiction to the provinces contributed to strengthen and promote the growth of hierarchies within institutions, differentiating those who had historically been under the control of the State prior to the resolution (and that now are informally called "ex national schools") from the "provincial schools".

This introduces great differences with the SEU. In the SIES the intervention of the State in designing the curricula, hour load, and evaluation methods of teachers and students, among other things, was considered common because of the history of these institutions as part of the secondary school educational system. On the contrary, the SEU has always considered itself independent of the State with regard to knowledge production and internal policies, to such an extent that it managed to set the autonomy of universities, as well as financial autarchy, in the article 75, subsection 19 of the Argentine National Constitution in 1994.

Still, despite its current legal classification, it has a historical and institutional tradition loaded with esteem that reinforces the identity of the members of the university (Vacarezza, 2006: p. 33). In this sense, it is worth mentioning the importance of the concept of autonomy and that it will be properly expanded; but, in the framework of the comparison between the SIES and the SEU it is a fundamental difference that helps to understand the contrasting traditions of both subsystems.

Furthermore, said subsystems also manifest significant differences in relation to student and teacher profile - taking into account the Socioeconomic Status; socio-educational status of students, their parents, and teachers; geographical origin; areas of professional practice; and their connection with the labor market and the State.

Taking into consideration the fact that both subsystems are very complex, it is impossible to encompass their characteristics and complexities in detail in a few pages; here are some examples to illustrate said difficulties: the SEU comprises 1,808,415 students and 123 institutions ${ }^{5}$, both public and private and foreign and international, while the SIES consists of a number of institutions that combined add up to 2465 units and a total of

${ }^{2}$ For a comparative view between the origins of teacher training systems in Latin America, see Salgado Peña (2006). "La formación docente en la región: de las normales a las universidades”, in Informe sobre la educación superior en América Latina y el Caribe 2000-2005, Caracas, Instituto Internacional de la UNESCO para la Educación Superior de América Latina y el Caribe.

${ }^{3}$ References about the diversity of technical schools and its origins and history can also be found in: Weinberg, D., La enseñanza técnica industrial en la Argentina 1936-1965, ITDT, Buenos Aires, 1967; Tedesco (1977), Industrialización y educación en la Argentina, PNUDDEALC/1; Wiñar (1970), Poder político y educación. El peronismo y la Comisión Nacional de Aprendizaje y Orientación Profesional, ITDT Buenos Aires, 1970.

${ }^{4}$ For example, in 1944 the distribution of enrolment in the official technical education by type of institution accounted for $49.5 \%$ of the total of students from technical schools, which began being more important in said subsystem. (Source: Weinberg, 1967). La enseñanza técnica industrial en la Argentina, 1936-1965, Buenos Aires: ITDT).

${ }^{5}$ When this work was written the following were counted: 3 provincial universities, 48 national, 1 foreign and 1 international, 6 national institutes, 14 private institutes, and 50 private universities. Recovered from:

http://portales.educacion.gov.ar/spu/sistema-universitario/listado-de-universidades-e-institutos/ 
767,698 students; which shows the high rate of dispersion on the second case in comparison with the great concentration of the first one, moreover when 58 out of 123 institutes are located in the City of Buenos Aires and its suburbs. For this reason, the differences between the two systems will be schematized in relation to the already mentioned topics in a general way.

If we analyze the profiles of the teacher staff, it can be noticed that the activities practiced in each subsystem are different. A significant difference in the teacher's activities, comparatively speaking, is that in the case of the SIES the focus is primarily on education; whereas in the SEU other activities, like investigation and university extension, are included.

Moreover, it can be noticed, according to the National Census of Teachers of $2004^{6}$, that only $3.9 \%$ of kindergarten teachers, $5.09 \%$ of elementary school teachers, $10.6 \%$ of middle school teachers, and $13.98 \%$ of SIES teachers had a teaching degree issued by universities. If this percentages are to be compared with those of 1994 (2.5\%; $1.3 \% ; 6 \%$ and $7.4 \%$ respectively), a growth in the amount of teachers graduated from universities can be observed.

Therefore, it can be noticed that there exists a professional practice area in which the SIES and SEU subsystems generate graduates that may end up being part of the same labor market: teaching in high schools and tertiaries, where there can be found a growing percentage of teachers with university degrees that vary according to the discipline (the percentages are higher among human science in comparison to natural science). A second area of competition can be noticed among some courses in technical-vocational institutes within the SIES and university graduates, especially in artistic, design or journalism courses.

Nonetheless, the fact that these professions may share the same areas of professional development does not necessarily imply that the graduates of each subsystem actually work and compete within the same environment: this happens because, generally speaking, in those environments where professional skills are similar, the degree of a university graduate is socially considered as more superior than that of graduates from institutes belonging to SIES.

Furthermore, there are researches ${ }^{7}$ that have made a profile of students within the Higher Education System in Argentina: it contrasts students of the SEU with those of the SIES, characterizing and differentiating the profiles of each subsystem in terms of their parents' educational level, sociodemographic factors, middle school of origin, how they gained admission to the various institutes of higher education, previous studies, and work related to the chosen course of studies.

While these pieces of research are more than 10 years old, some of their conclusions are still valid and will be summarized in the following items:

- There is a link between academic level and socioeconomic status in both subsystems;

- The socioeconomic profile of the students from the SIES corresponds with a lower-income population;

- With regard to travelling, students with more resources usually travel to SEU institutions, while lower-income students choose tertiary courses in the SIES due to travelling difficulties and in order to quickly find a safe job in the State; which in certain extent explains the previously mentioned dispersion of this subsystem;

- There is a high correlation between the educational level of the parents, performance in middle school and placement and admission tests (when they exist), and the admission to one system or the other;

- In many cases, choosing a technical course of studies in the SIES is a step towards starting another one in the SEU.

These conclusions arise from various statistical data; for example, if the "socio-educational status of parents" factor is to be analyzed comparatively, it will be observed that $18.9 \%$ of students belonging to the SEU stated their mothers have a university degree; while in the case of SIES students, that percentage decreases to a $7.1 \%$. In the case of the educational level of fathers, the figures are $25.8 \%$ and $8.6 \%$ respectively.

\footnotetext{
${ }^{6}$ The final report of the National Census of Teachers of 2014 was not available when this work was written.

${ }^{7}$ Just to mention some, references can be found in Kisilevsky \& Velada (2002). Dos estudios sobre el acceso a la Educación Superior en la Argentina. Buenos Aires: IIPE-UNESCO; Kisilevsky (1999). Estudiantes de Formación Docente, Universitarios y Maestros: Perfiles y Circuitos. Buenos Aires: Mimeo; Birgin, Pineau, Cangenova, \& Poliak (Coord.) (2003). "Docentes con raros peinados nuevos: el perfil de los estudiantes de primer año de las carreras de formación docente de la Ciudad de Buenos Aires” en Encuentro de formadores-as de docentes de la Ciudad de Buenos Aires. Experiencias y Perspectivas. Dirección de Educación Superior, Ciudad Autónoma de Buenos Aires; Cámpoli (2004). La formación docente en la República Argentina. Buenos Aires: IESALC. Tenti Fanfani (Coord.) (2010) Estudiantes y profesores de la formación docente. Opiniones, valoraciones y expectativas. Buenos Aires: Ministerio de Educación de la Nación.
} 
The percentages are different even within the SIES itself if teacher training and technical-vocational institutions are considered separately. In the first case, the proportion of parents with less education is higher. Considering some general features, some of the characteristics of students are shown in Table 1 and Table 2, in relation with the educational level of the parents.

Another significant characteristic of those students who start courses in the SIES is related to previous studies: the percentage of students who enter the system having previously started other courses (about a 30\%) —of which half (56.5\%) had started university courses — decided to abandon those and start attending a SIES institute. This means that, for this group of students, studying in higher education institutes was not a first option nor was it what they wanted.

In the case of the SEU, the percentage of students who started another course decreases to a $20 \%$. However, the overwhelming majority of students in this group changed courses but within the SEU system.

Regarding work activity while studying, as shown in Table 3, the analysis of condition of activity shows that the proportion of university students who work is higher than that of the SIES system, but at the same time, the percentage of students from the second group who search for a job is higher. This can be observed in the statistics referenced in Table 3:

These figures must be understood in relation with the income quintile of the families which, as shown in Table 4, is higher in the students belonging to the SEU. However, Table 5 indicates that there are not significant differences in the way of financing the studies, exposing also a meaningful low impact of scholarships assigning all the responsibility of the finance to the family of the student (even though it has to be considered that the public sector is the most important in both subsystems and it's free of charge and unrestricted.

Table 1. Educational level of the mother.

\begin{tabular}{ccc}
\hline Educational level of the mother & SIES & SEU \\
\hline N/A & 6.1 & 4.9 \\
Elementary school (complete) & 1.1 & 0.3 \\
Elementary school (complete) and High School (incomplete) & 46.1 & 28.5 \\
High School (complete) & 33.4 & 38.2 \\
SIES & 6.1 & 9.3 \\
SEU & 7.1 & 18.9 \\
Total & 100.0 & 100.0 \\
\hline
\end{tabular}

Table 2. Educational level of the father.

\begin{tabular}{ccc}
\hline Educational level of the father & SIES & SEU \\
\hline N/A & 22.6 & 21.1 \\
Elementary school (complete) & 0.2 & 0.4 \\
Elementary school (complete) and High School (incomplete) & 33.3 & 19.3 \\
High School (complete) & 32.7 & 30.8 \\
SIES & 2.5 & 2.6 \\
SEU & 8.6 & 25.8 \\
Total & 100.0 & 100.0 \\
\hline
\end{tabular}

Table 3. Condition of activity.

\begin{tabular}{ccc}
\hline Condition of Activity & SIES & SEU \\
Employed & 56.8 & 50.3 \\
Unemployed & 12.9 & 9.8 \\
Inactive & 30.3 & 39.9 \\
Total & 100.0 & 100.0 \\
\hline
\end{tabular}


Table 4. Income quintile.

\begin{tabular}{cccc}
\hline Income Quintile & SIES & SEU \\
\hline N/A & 0.1 & 0.3 \\
I & 11.9 & 5.2 & 10.6 \\
II & 16.4 & 20.2 \\
III & 23.1 & 29.8 \\
IV & 28.2 & 33.9 \\
V & 20.3 & 100.0 \\
\hline
\end{tabular}

Table 5. Way of financing studies.

\begin{tabular}{ccc}
\hline Way of financing studies & SIES & SEU \\
\hline With family contribution & 64.2 & 62.7 \\
Whit personal work & 22.6 & 22.8 \\
With work and family contribution & 9.6 & 12.4 \\
With family contribution and scholarship & 1.6 & 0.9 \\
Whit personal work and scholarship & 0.4 & 0.5 \\
With scholarship & 0.7 & 0.3 \\
N/A & 0.7 & 0.3 \\
\hline
\end{tabular}

Statistics about the amount of students' working hours (of those who have jobs) in each subsystem could not be found, nor the type of job they perform — especially if it is related with the chosen course or not; which would be a significant comparative item in order to know if the jobs are to finance various aspects of everyday life (studies, family and/or social life), if students work to gain another area of training and to enter the professional world, or if they work just to be busy or to have extra income. In addition, the same circumstances can be thought depending on whether students have part-time or full-time jobs.

At the same time, if the geographical origin of the students of both levels is observed, two pronounced characteristics can be found: on the one hand, the areas of the country with the highest ratio of young people placed in the top quintiles have a higher proportion of students in the SIES than in the SEU when compared with other areas; and they even have more students in teacher training institutes than in technical-vocational institutes.

This occurs for various reasons: firstly, it can be observed that while the SEU system has only 123 institutes (of which 58 are located in the Autonomous City of Buenos Aires and its metropolitan area, and most of the remaining institutes are located near other populous cities of the country), the SIES encompasses 2465 units geographically distributed throughout Argentina as shown in Figure 1.

It is manifest that choosing university courses that imply travelling is conditioned by the student's economic status; on the other hand, the social demand of teachers, which has extensive distribution throughout the country, is chosen by students who are less likely to travel.

The socioeconomic constraints that reduce the possibilities of travelling to study are one of the main factors that make students of teacher studies mostly attend to institutions in their place of origin. Therefore, it could be said that, in general, teacher studies are an option for those students with less resources-as these are short, less expensive courses that allow a rapid entrance into the labor market and offer the possibility of working and studying simultaneously.

As it can be observed, choosing a tertiary course of studies in SIES institutes is a common option for young people with lower socioeconomic status, if analyzed in comparison with universities. In general, teacher training institutes have a higher percentage of women (77\% at present), while in technical-vocational institutes this figure 


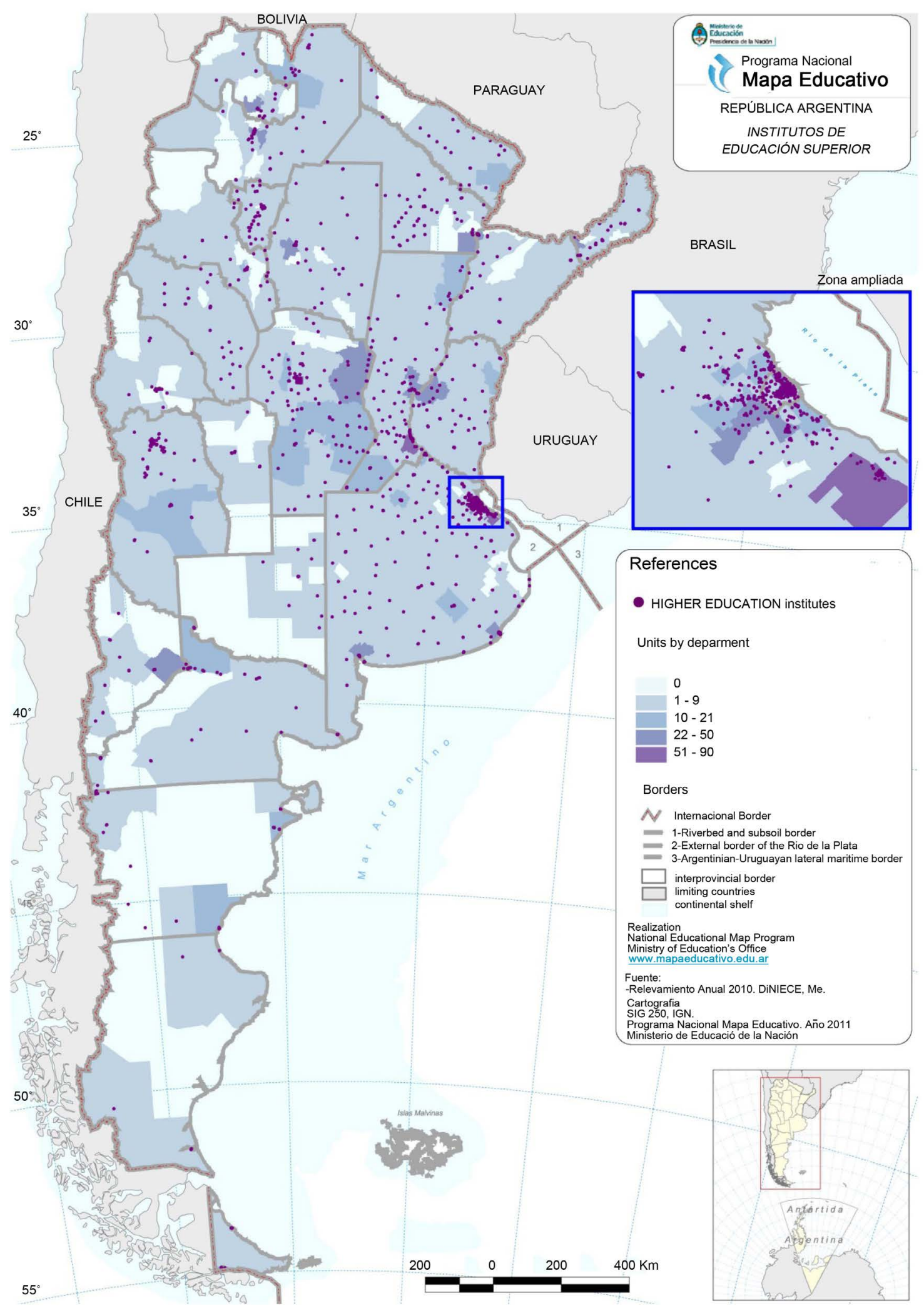

National Educational Map-Higher Education Institutes.

Figure 1. National educational map-ministry of education of Argentina. 
decreases $^{8}$; in both cases, studying in the SIES is an alternative for subjects from the lower quintiles of society who seek higher level qualifications presuming it will facilitate access to employment.

Likewise, if the analyses of personal and academic paths of the students from the SIES are considered together with the organizational characteristics of training institutions (Merlo, 2007), it can be noticed that the institutional culture of the SIES replicates a school model that only considers or provides one ideal of school career-whose duration is standardized and determines a regulated progression of learning; as opposed to the case of the SEU, whose route for students through different subjects is much less structured.

Summarizing, the main differences between both subsystems can be schematized in the following items. There are two subsystems that are considered higher education, as they are studies performed after high school, but that:

1) The social composition of each of these systems (of both students and teachers) is different;

2) The distribution and geographical range also varies (a factor closely related to the social composition);

3) Graduates from each of the subsystems work in different sectors of the labor market;

4) Institutional cultures are significantly different, especially regarding traditions of teaching, autonomy, links with society, with the state, and with scientific research, among others. There is also an implicit hierarchical distinction between both types of institutions;

5) Finally, the method for budget allocation, the institutional and curricula organization, classroom practices and institutional life itself vary.

\section{The University Educational System (SEU)}

As previously mentioned, the University Educational System followed a path different to that of the SIES, partly because of historical traditions, as well as institutional configurations, people who participate within each subsystem, and the different relations they have with the market, the State and the rest of society. Having already distinguished both subsystems, this section will focus on the SEU. Firstly, a historical overview of Argentine universities will be made, focusing on the emergence of universities and their different cultural and institutional traditions. On this basis, a typology of different universities, where seven distinct groups stand out, will be made.

This typology was organized based on how the actors involved in said institutions and their institutional cultures were historically shaped. For this purpose, some historical events that contributed to the current configuration of the SEU will be resumed. Finally, the last section will make a schematic characterization of the actors involved in the SEU, mainly focusing on students and teachers using information from the university censuses.

Different traditions can be observed within the SEU, and the following typology stems from those clearly differentiated traditions. In relation to public and national universities, they shall be divided into 6 groups:

1) Traditional Universities (UBA, UNC, UNLP, UNT, UNL, UNCu);

2) Developmentalist ${ }^{9}$ Universities (UNT, UNNE, UNS, UNMDP, UNR);

3) Taquini Plan ${ }^{10}$ Universities(UNRC, UNCo, UNCa, UNLZ, UNSa, UNER, UNJu, UNLPam, UNLu, UNaM,

${ }^{8}$ According to the OIE’s report, Sistema Educativo Nacional de Argentina (National Educational System in Argentina; Pulfer, 1993), "Even considering the high rate of females in teacher studies (except in non-teacher specialties and the physical education specialty) the attention is focused on what could be called 'increasing feminization according to lesser level', which corresponds to the situation of teachers in the educational system: the low percentage of male enrolment increases as one moves from regular studies for teaching in pre-elementary levels to those that train teachers for elementary and high school. The picture of kindergarten run by women only, elementary school with some male teachers and high school with an already sizeable proportion of male teachers (a result of the relatively recent introduction of coeducation in middle school, among other things), is corroborated by the sex ratios of relevant specialties of non-university higher education. Analyzing the male ratio of enrolment in various bodies, it can be perceived that enrolment in technical and industrial, agricultural, military and police have a high male ratio, while non-university higher institutes destined for the preparation of artistic, cultural and other educational activities are distinguished by strong female presence” (own translation, 1993: p. 6).

${ }^{9}$ Developmentalist in this context allows to a certain political and economic position that was very strong between the mid-40s and the late 60s in third world countries that has its philosophical background in the Theory of Development.

${ }^{10}$ The Taquini Plan (decree 20,753) was a project to create public universities during the self-called "Argentine Revolution” military dictatorship (1966-1973). The aim of the creators of the plan was to find a solution to the demographic effects produced by the great movement of young people from various provinces of Argentina towards the metropolitan centers, where the most important universities were located. Furthermore, they also aimed to promote the development of research more linked to local industries and production with an alleged plan to decentralize the development of said industries. However, the creation of the Taquini Plan cannot be disassociated from the Cordobazo, which involved a series of revolts in 1969 by students and workers and prompted the resignation of the dictator Onganía. The Taquini Plan was partly originated in order to prevent the concentration of the student masses in the large cities within a framework of strong social discontent and political polarization of the students. Moreover, further analyses suggest that the Taquini Plan, despite its explicit goals, not only failed to decentralize the development of research but also ended up reproducing the regional inequalities that it tried to avoid by concentrating the best teacher and research bodies in the most prestigious institutions (Civarolo de Gutiérrez, 1986). 
UNSJ, UNSL, UNSE, UniCen y la UNPSJB $\left.{ }^{11}\right)$;

4) “End of Century” Universities (UNF, UNLaM, UNQ, UNSaM, UNGS, UNLaR, UNPA, UNLa, UNTreF y UNVM);

5) “Third Millenium” Universities (UNChi, UNNOBA, UNCAus, UNRN, UNAJ, UNDAV, UNJP, UNMo, UNO, UNTDF, UNA y UND);

6) And, finally, university institutes.

Furthermore, the characteristics of private universities in the Argentine SEU will be described taking into consideration that most of the enrolment, research, knowledge transference and international circulation, among other aspects, is concentrated in public universities.

Private Universities: here can be found UADE, UAJK, CAECE, UCA, UCCo, UCCu, UCLP, UCS, UCSF, UCSE, UB, UCU, UMe, UMo, UMM, UNSTA, US, UJAM and UNA, UAI, UALP, UAA, UA, UBP, UC, UCES, UC, UFlo, UCP, UP, USA, UCEMA, UCEL, UC, UES21, UF, UFav, UMai and UTDT; and private management university institutes: ITBA, CEMIC, IUCS, ESEADE, IUGD, IDEA and ISALUD. Nevertheless, differences within this group will also be described.

As mentioned above, this typology was developed from some historical distinctions that are, on the one hand, connected by the context of its foundation, but also with different traditions and composition of the subjects that are part of them, that result in a heterogeneous institutional ethos.

The first university founded in the current national territory was the University of Córdoba, created in 1613 by the Society of Jesus, although after the expulsion of the Jesuits from Spain the institution was transferred to the Franciscans. Once Argentina was an independent country, the university was put under provincial jurisdiction and finally, in 1856, it was integrated into the national government in conjunction with the University of Buenos Aires, founded in 1821.

These two universities were the only that functioned as such during the second half of the nineteenth century, the period of formation of the Argentine Nation State (Ozslak, 1997) ${ }^{12}$. With the consolidation of a central state begins a strong process of an illumino-positivist matrix that separated the church from the universities. A Napoleonic university tradition (Krotsch, 1995) was strengthened in those faculties with the most strong professional emphasis (like Law Faculty or Faculty of Medicine) and a Humboldtian tradition in faculties dedicated to arts and science (like the Faculty of Natural Sciences or the Faculty of Philosophy); but above all, these universities were erected for the education of the ruling class, especially the oligarchy of the main Argentine cities, with a professional profile for subsequent employment at different hierarchical State sectors.

These universities were later joined by the following: the National University of La Plata (1905), the National University of Tucumán (1914), the National University of Litoral (1919) and the National University of Cuyo (1939); these are considered to be the Traditional Universities of Argentina (Mollis, 2001; Gómez Campo \& Tenti Fanfani, 1989) among others. Having already had a consolidated National State and a rising middle class, one of the events that began shaping the current configuration of this group of universities was the Argentinean University Reform of 1918.

This event should be considered within the context of an increased access of the middle classes to the university system, traditionally reserved for aristocracy (not just for students but also mainly for teachers and researchers), and that it developed during the first mandate of the Radical party, which at that time attended the demands of Argentina's middle class. The Reform of 1918 was a series of student demonstrations that promoted a number of changes to the SEU, which can be summarized as follows:

1) University autonomy;

2) Unrestricted admission (education as a right);

3) Access to teaching by public competition comparing opposing positions and backgrounds;

4) Free chairs (discussion on the production of knowledge);

5) Acknowledgment of democratically elected student unions and co-governance.

\footnotetext{
${ }^{11}$ The list of the Patagonia National University "San Juan Bosco" is included because, although its founding date is considered to be 1980 after the merger of Patagonia and San Juan Bosco universities, its antecedent (the Patagonia National University) was created under the Taquini Plan on May 4, 1974.

${ }^{12}$ In fact, the Santa Fe University (currently the National University of Litoral) and the current National University of La Plata were established as provincial universities in October 16, 1889 and February 8, 1897 respectively. But the reality is that due to the proximity of the city of Rosario and La Plata to Buenos Aires (where they competed with the most prestigious university of that time) and that they still could no tissue national titles until their nationalization on January 1, 1905 in the case of the UNLP and October 17, 1919 in the case of Litoral, it can be stated that they were not significant in the university system of that time.
} 
Many authors (Mollis, 2008; Sader, Aboites, \& Gentili, 2008; Vidal, 2005) agree that the scope of the Reform was quite limited at the time. However, one of its greatest accomplishments was to subsist throughout history as a founding myth of university demands. Since that moment on, virtually all university demands alluded to "the spirit of the Reform" to give legitimacy to the demands. In this sense, the story of the Reform and the circulating social discourses about it were more important than the events that occurred in 1918.

Each of the demands driven under the Reform of 1918 was resumed in different historical moments and under the sign of different interpretations; however, some were more significant than others.

The case of unrestricted admission, also called free admission or direct admission (Chiroleu, 1998), was a long-debated university policy upon the dichotomous figure of "selectivity vs. democratization" regarding university admission. The discursive logic under which the mechanism of admission to public universities was publicly discussed was organized in binary positions based on certain premises of a mythological character (Barthes, 1981): in the case of the supporters of selective admission, the emphasis was on the alleged preservation by means of this path of the supposed high standards of academic quality that would allow the university to "focus on the very best"; while in the case of the unrestricted admission, the prevailing discourse was associated with the ideals of social justice and equality of opportunity. The fact that selective admission was established on two occasions by dictatorial governments (in the self-called "Revolución Libertadora" in 1955 and "Proceso de Reorganización Nacional" in 1976) ${ }^{13}$, and that unrestricted admission was established during three different democratic governments (in 1953 during Peron's second mandate; in 1973 during Héctor Cámpora's short mandate; and in 1983 with the return of democracy in the Alfonsin's government) resulted in strengthening the debate over the phenomenon regarding said dichotomy. Now, after the enactment of the Higher Education Law, each university and each faculty with more than 50 thousand students can set their own admission logic (this is how the Faculty of Medicine of the National University of La Plata established an entrance examination while the rest of the university maintains a system of unrestricted admission).

However, the fact that social selectivity may take different forms and even be masked behind seemingly "democratic" positions cannot be disregarded. In this sense, unrestricted admission does not necessarily mean greater democratization of education, since the alleged equal opportunities given to all candidates to develop their potential through university studies implicates (even though it removes the incidence of adscriptive elements) unequal chances of success from diverse socioeconomic and cultural backgrounds. Some authors even distinguish between formal access to institutions and real access to knowledge (Tedesco, 1985).

With regard to requests for access to teaching by public competition and opposition, the main demand focused on that teacher shall be summoned by public competition and not "hitherto anointed by complacency and camaraderie" (own translation from Anonymous (1918) author on the journal "La Gaceta Universitaria"). This was one of the aspects where the Reform of 1918 had more influence. It attained the implementation of some

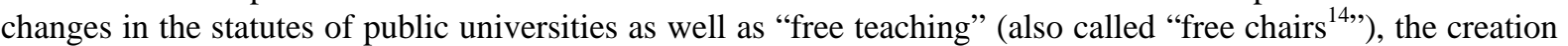
of academic careers, and also matters concerning the incorporation of science and technology into the academia (Buchbinder, 2003: p. 138).

The acknowledgement of student unions as organizations that channeled the demands of the student body and also their active participation in a tripartite government composed of teachers, graduates and students in order to settle university policies (the "tripartite government") was another demand from the Reform that became effective in several houses of studies during that year.

Finally, another of the ideological signs that were a class conflict arena (Voloshinov, 1976) revolved around the concept of university autonomy. This debate did not started during the events of the Reform in 1918; it can even be traced back to The Conflict of the Faculties (Kant, 2004), written by Kant in 1794 when European liberal universities were emerging against scholastic cloisters. That deeply modern and enlightened legacy was adopted by the Argentine government as a reason to eradicate the Church from institutions of higher education, from whose classrooms emerged most of the political aristocracy of the time, and which Cano (1985) exemplified with the phrase "from university to power and from power to university".

Nonetheless, the notion of autonomy kept transmuting its meaning and its ideological-discursive uses over the

\footnotetext{
${ }^{13}$ Translator’s Note: “Liberation Revolution” and “National Reorganization Process” respectively.

${ }^{14}$ This aspect refers to the possibility that different teachers, graduates and even student organizations could instruct students in a discipline, a phenomenon or other things for the purpose of disseminating areas of culture and knowledge that were not specified in the academic curricula. The university ought to provide classrooms for these activities to be developed, although these did not have any formal link with the institution.
} 
years; to such an extent that in the University Reform of 1918 that idea of autonomy which had been used by the political oligarchy of the late nineteenth century in Argentina to face the Church regarding the hegemony of production and institutionalization of knowledge, was adopted by reformers to face that same oligarchy which, thanks to teacher selection system, in which they evaluate themselves their colleagues and this was supported by the national Executive Power (which traditionally had the same hegemonic-political importance than that of the university faculty), the university oligarchy had an established mechanism to retain their places in the hierarchical positions of that institution.

While the relationship with the State had not changed significantly (if the period prior to the Reform of 1918 is compared with the following period), the notion of autonomy became an empty signifier that was filled with meaning in every demand, fight, or university-related protest. That was the case of the Reform of 1918, but also the case of government interventions in Justo's and the Peronist governments in the 40s (Buchbinder, 2003: p. 148), the case of successive military governments, and the debates regarding the approval of private universities (the "Secular or Free" debate), among many others.

The dispute over the scope of the autonomy, for the purpose of defining university internal policies and its relationship with the State, was continual in university history. The debate went so far that, under the figure present in the National Constitution, the University of Buenos Aires brought legal proceedings against the National State: It claimed that the Higher Education Act (LES, by its Spanish acronym) was unconstitutional; which concluded in not applying the LES to said university. It is of interest to note in this case how the debates on autonomy materialized in specific situations such as the legal conflict between the UBA and the State; but also on different elements of the institutional life of public universities ${ }^{15}$. On the other hand, it was also a speech that leads to the hindering of policies coordinated between the university, the State, the private sector, and society (Beigel, 2010).

As it can be seen, these series of student protests, as a part of what later became known as the Reform of 1918, acquired over time a mythical status to such an extent that virtually all political mobilizations in relation with universities evoked that event. The most important demands have been transformed and changed in consonance with different times, but always evoking the memory of said event. As Vidal (2005) says:

The University Reform of 1918 became a mythical event par excellence. For that reason, people confer a number of different connotations in extremis. These constructions meant in the practice a battle sometimes open, sometimes hidden among political parties, ideological lines, historiographical positions, etc. in order to try to appropriate this complex and poorly analyzed event (Vidal, 2005: p. 188).

This historical Event (Foucault, 1979: p. 230) must be interpreted in the context of a historical process that allowed, at the same time, the emergence of most diverse phenomenon in relation to the university, and that somehow explains its configuration and institutional culture in an intricate web of relationships that intertwine to attach some practices nowadays.

Traditional universities are hence those that emerged or strengthened under the wing of the Reform of 1918, and those where the debates about unrestricted admission, tripartite government, and above all, university autonomy were forming a particular ethos that explains to a great extent its relationship with society, the market and the State. For some sectors, said autonomy resulted in an "elitist" conception of science associated with isolation (Nowotny, Scott, \& Gibbons, 2002: p. 84), which intensified the already strong basic tension between the scientific role and the social role of the university, built under the mythical dichotomy of quality/massification (Vaccarezza, 2005).

What should be highlighted is that the remaining six groups of the typology referenced in this work comprise universities that shaped an institutional ethos as opposed to some characteristics from traditional universities, which have always had an hegemonic position (Gramsci, 1975: p. 32) in the academic field-both in relation to prestige towards their teachers, graduates and students, as well as the scope and quantity of research. It can be seen as an enigmatic figure that, while there are 123 institutions comprising the SEU, the six "traditional universities" make up about one third of the national student enrolment: 635,000 students out of a total of 1,808,415.

Developmentalist Universities include universities created during the period of industrialization in Argentina (from the 40s to the 60s), from the first government of Perón until the outset of what was called the Taquini Plan.

\footnotetext{
${ }^{15}$ For more information on university autonomy in Argentine universities see Vaccarezza (2005). About the legal litigation between the UBA and the Federal Government in relation to the LES, see (Naishtat, Toer, \& Aronson, 2005: p. 47).
} 
These universities initially focused on some subject areas (for example, UTN focused on the branches of engineering, UNMDP on urban planning and architecture) or were the result of the provincialization ${ }^{16}$ of national territories (UNNE; UNR).

In this sense, the institutional culture in dispute in this second type of universities is related to the dichotomous discourse that categorizes universities into those considered more "academic" and those with a "practical or professional nature". In this sense, the Developmentalist Universities were placed on the second side of the dichotomy, seeking greater coordination with the emerging industrialization in Argentina during said period, and especially in coordination with the economic plans of the governments of the time.

On the other hand, the emergence of the universities from the Taquini Plan cannot be understood disregarding the conflict between traditional universities and the self-called "Argentinean Revolution" dictatorship. As mentioned in footnote No. 9, the relationship between said dictatorial government and the universities began with the State intervention in universities in 1966, in an event called "the night of the long canes"; however, the tension between the university and the government did not end there: between 1966 and 1969 there were a series of events that culminated what was later called Cordobazo, which led to the resignation of the dictator Onganía.

The new executive, Marcelo Levingston, who was also a member of the military board of the time, activated the Taquini Plan as a strategy to resolve the conflict the government had with the large student rally in the big cities (within a framework of strong social discontent and the political polarization of students) without intervening in universities in a direct way in order to avoid direct conflict. Thus, 15 universities were founded between 1971 and 1974 and this project became the most ambitious one regarding the creation of public universities in Argentina.

Moreover, as consigned in footnote no. 10, further analysis suggests that the Taquini Plan, despite its explicit objectives, not only failed to decentralize the development of research but ended up reproducing regional inequalities, which it tried to avoid by concentrating the best teachers and researcher bodies into the most prestigious institutions (Civarolo Gutierrez, 1986).

While the bond of these universities with the dictatorial government was soon dissolved-largely due to the substantial change of the profile of the government that assumed in 1973, when said universities began to get organized - they kept their original profile: to give response to the demographic needs of the growing remote towns (while thus avoiding the concentration of a student body in Buenos Aires, the political and economic capital), and an orientation towards regional development, with closer links to the context in which they are located.

Those designated as "End of Century" Universities refer to institutes created during the period of 1988 to 1995. Although in this case, like traditional universities they had a professional profile, its young graduates are not involved in the historical process of forming a political class engaged in a national direction as it does happen in the first universities. In short, the professional preparation of traditional universities embodies a public ethos, while in the case of "End of Century" universities there is a focus on a corporate ethos, shaped by the demands of a small job market that requires an instrumental and efficient rationality for the performance of professions in private corporations (Nun, 2001).

Regarding the 12 "Third Millennium" Universities, in most cases a clear profile that defines an institutional culture cannot be observed, but it should be noted that seven of the twelve were founded around Buenos Aires City. Like "End of Century" universities and unlike Traditional universities—which were consolidated under the model of the Reform of 1918 and that posed as main demands the autonomy, the tripartite government and unrestricted admission, as well as free-of-charge education as its main principle-one of the purposes of creating new public universities in the suburban area of Buenos Aires:

"Was to change the reformist model of traditional public universities by transforming the key operational criteria. The traditional university governance was replaced by a university management body committed to obtaining alternative resources, unrestricted admission was replaced by a selective admission, free-of-charge education was replaced by a voluntary fee collection, auxiliary teachers by temporary hired teachers” (Mollis, 2008).

\footnotetext{
${ }^{16}$ To prevent uninhabited territories could be considered res nullius by other countries, by Law $\mathrm{N}^{\circ} 28$ the $17^{\text {th }}$ of October 1862 it was decided that all existing territories outside the limits or possession of the provinces are "national territories", meaning that were directly supervised by the national state and didn't have the status of a province. The provincialization of the national territories was a process that started in the $8^{\text {th }}$ of August of 1951 when the National Territory of Chaco was declared as province and that ended on November 22th of 1956 with the provincialization of the National territory of Santa Cruz, with the exception of Tierra del Fuego that was declared as a province in 1990.
} 
The group comprising university institutes and provincial, international and foreign universities based in Argentina was sorted as such despite the differences between its components, since its percentage within the total of university students as well as its participation in the scientific and academic activity of the country is significantly lower in comparison with the other groups surveyed. This group comprises the following provincial universities: UADER, UNIPE, UPE and UPSO; there is also a building of the University of Bologna as a unique case of a foreign higher education institute operating in Argentina; the Latin American Faculty of Social Sciences develops its academic activity (especially in relation to postgraduate and research) as the only international university; and finally seven State University Institutes, of which six belong to different sectors of the army: IESE, IUA, IUP, IUSM, IUN, IUGN and the National University Institute of Human Rights "Madres de Plaza de Mayo". However, all the named cases respond to institutes that were established in the country after the enactment of the Higher Education Act and do not have a unified tradition: in the case of military institutes, these are closely related to military functions and interests. On the other hand, provincial universities are cases that seek their reclassification towards a national orbit; finally, the foreign and the international university (Bologna and FLACSO) focus primarily on postgraduate courses.

Finally, it is worth mentioning the place that private universities occupy. It should be remembered that the emergence of privately run universities is very recent in Argentina's history, since these institutions were only allowed to issue official titles after the enactment of the No. $14.557 / 58$ Act in $1958^{17}$, better known as the Domingorena Act.

However, many of the institutions that were formalized as universities in 1958, after the "Secular or Free" ${ }^{18}$ debate, had already existed as tertiary education institutes or functioned as research centers prior to that date (that is the case of the Argentine Catholic University, Salvador University or the Museo Social Argentino University to cite a few examples).

While different stages can be distinguished in terms of the modifications introduced with each government in Law 14,557, it can be said that the stage which started in 1958 continues in another way in the mid-80s, when the antinomy of Church and State fades and, with globalization and the emergence of neoliberalism, the market opposes the concept of public education run by the State.

In this sense, different institutional cultures can be observed in relation to privately run universities. This permits to classify mainly considering the institutional ethos and the institutional traditions of each one of them. In relation to this, the following are distinguished:

1) Private universities of a confessional character. Driven, created and developed by the Jesuits, Dominicans and to a lesser extent by other churches, like the Adventist, Evangelical, Opus Dei and the Jewish community. Institutionally supported by the founding church hierarchies, they adopted organizational models that combine and share the functions between secular and religious authorities. As previously mentioned, they were the first to be formalized as they had already been functioning as educational institutions; thus, from the eleven universities recognized upon the Law 14,557, eight were of Catholic origin. Unlike the other types of private universities, confessional universities are better distributed in the Argentine territory and have higher enrollment in comparison with the rest of the private universities.

2) A second group is composed of self-called business universities, which mainly respond to foundations linked to enterprises and chambers, or foundations of economic or business studies. The first two groups are universities that currently have a strong professional profile, with little or no scientific careers but rather focused on a job market that requires an instrumental rationality in the private sector, being sharper in the case of business universities.

3) Another group is composed of academic universities, which indicate and develop integrated teaching and research. The teacher staff has full-time dedication to these two activities and they produce a significant

\footnotetext{
${ }^{17}$ Prior to said Act there is the antecedent of Decree Law 6403/55, sanctioned during the self-called "Liberation Revolution" dictatorship, which legislated the organization of national universities and which in its Article No. 28 permitted the operation of Private Universities. The No. 14.557 law used that antecedent and authorized (already in democracy) the operation of private universities after a prolonged conflict that began in August 1958 and lasted until 1960, in what is known as the "Secular or Free" debate.

${ }^{18}$ For more information on the discussion mentioned above there is the article from Horacio Sanguinetti: "Laica o Libre: los alborotos estudiantiles de 1958”, in Todo es Historia, año VII, No. 80, January 1974, p. 9-23 and chapter “Dos ciudades: Laica o Libre”, in José Zanca’s book: Los intelectuales católicos y el fin de la cristiandad 1955-1976, FCE, Buenos Aires, 2006, pp. 85-135, that addresses the issue from a Catholic perspective. Also, a significant number of documents on the issue are compiled by Luis O. Roggi in Argentina, enseñanza superior 1958, CIDOC, Dossier, No. 10, México, 1967, and to a lesser extent Horacio O. Domingorena in Articulo28universidadesprivadasen la Argentina. Sus antecedentes, Americana, Buenos Aires, 1959.
} 
amount of research in comparison with the remaining groups of private universities also focused on the development of postgraduate careers.

4) Some universities that are part of international projects and depend on foundations that develop educational work in more than one country can also be identified. This group is integrated by transnational universities, which are still a small group considering that only $1.5 \%$ of the total offer of postgraduate courses corresponds to inter institutional programs; that is to say, created by the association or agreement between two or more universities, although these postgraduate degrees are mostly of a professional profile.

5) Finally, there are thematic or single-discipline universities or institutes, because their courses focus on particular or specific issues on which the founders groups have extensive experience, for example, Universidad del Cine (University of Cinema).

It is worth mentioning that private universities focus their academic offerings in humanistic, economic or artistic careers; while disciplines with distinct higher costs like technological or health careers (mentioned only for an illustrative purpose) can be found primarily on public universities.

\section{Conclusion}

After this brief description, it is worth saying that there are many aspects which are not mentioned and which are crucial in the development and organization of the University Education System.

This study sought to focus on historical traditions and institutional cultures of the Argentine SEU, mostly from the 1990s, when many changes that made the system more complex in an international scale as well as within itself were introduced.

From 1995 onwards, in Argentina—as well as in Mexico, Brazil, Bolivia, Russia, Bulgaria and Mongolia, among other countries in Latin America and the former socialist bloc-an "international agenda for the modernization of higher education systems" was installed, mainly promoted by international lending agencies like the World Bank and the Inter-American Development Bank (Marginson \& Mollis, 2001) which involved creating central bodies to evaluate and accredit university institutions, among other things (like the University Policies Secretariat [SPU, by its Spanish acronym], now called Ministry of Higher Education and National Commission for University Evaluation and Accreditation-CONEAU-) (Mollis, 2001).

These centralized evaluation and accreditation bodies were founded in order to classify universities under a quantitative "quality criteria" and under standardized (or "internationalized") specific international standards. This policy was strengthened with a tendency to build a model of higher education aimed at satisfying the global(ized) labor market, and that operated both in terms of knowledge transfer (more linked to teaching at university) as well as the production of knowledge (research), which were also governed under international classification parameters.

That is why as a final comment, this article account of the specific traditions of the different universities according to their particular history and institutional culture. However in addition to that argument developed under the subtitle "The University Educational System (SEU)", we have to add the national and regional traditions, meaning the logic under which these aspects are organized, as well as the place assigned to the instrumental knowledge and the subordinate place universities occupy outside the most important countries in said globalization of knowledge linked to the global dynamics of the hegemonic countries. This last aspect must be taken into account because of the significant changes that they are imposing on universities and on academic work.

\section{Acknowledgements}

Translation from Spanish: Sofía Lazzarino.

\section{References}

Anonymous (1918). El derrumbe de la bastilla [The Fall of the Bastille]. La Gaceta Universitaria N ${ }^{\circ}$ [The University Gazette No. 3].

Barthes, R. (1981). Mitologías [Mythologies]. México: Siglo XXI.

Beigel, F. (2010). Autonomía y dependencia académica. Universidad e investigación científica en un circuito periférico: Chile y Argentina (1950-1980) [Academic Autonomy and Dependence. University and Scientific Research in the Peripheral Circuit, Chile and Argentina (1950-1980)]. Buenos Aires: Editorial Biblos. 
Birgin, Pineau, Cangenova, \& Poliak (Eds.) (Coord.) (2003). Docentes con raros peinados nuevos: el perfil de los estudiantes de primer año de las carreras de formación docente de la Ciudad de Buenos Aires [Teachers with Rare New Hairstyles: The Profile of the First Year Student of Teacher Training Courses on the City of Buenos Aires]. In Encuentro de formadores-as de docentes de la Ciudad de Buenos Aires. Experiencias y Perspectivas. Dirección de Educación Superior, Ciudad Autónoma de Buenos Aires [Teacher Educators Meeting of the City of Buenos Aires. Experiences and Perspectives. Directorate of Higher Education, Autonomous City of Buenos Aires]. http://biblioteca.uahurtado.cl/ujah/reduc/pdf/pdf/00.753-03.pdf

Buchbinder, P. (2003). Historia de las Universidades Argentinas [History of Argentinians Universities]. Buenos Aires: Sudamericana.

Cámpoli, O. (2004). La formación docente en la República Argentina [Teacher Training in Argentina]. Buenos Aires: IESALC.

Cano, D. (1985). La educación superior en la Argentina [Higher Education in Argentina]. Buenos Aires: FLACSOCRESAL-UNESCO, Grupo Editor de América Latina.

Carli, S. (2012). El estudiante universitario. Hacia una historia del presente de la educación pública [The College Student. Towards a History of the Present Public Education]. Buenos Aires: Siglo XXI.

Chiroleu, A. (1998). Acceso a la Universidad: Sobre brújulas y turbulencias [University Access: On Compasses and Turbulence]. Revista Pensamiento Universitario [University Thoughts Journal], 7, 3-11.

Civarolo de Gutiérrez, M. (1986). Plan Taquini. Análisis, crítica y perspectivas [Taquini Plan. Analysis, Criticism and Perspectives]. Córdoba: UCC.

Dussel, I., \& Pineau, P. (1995). De cuando la clase obrera entró al paraíso: La educación técnica estatal en el primer peronismo [When the Working Class Entered to Paradise: State Technical Education in the First Peronism]. In A. Puiggrós, \& S. Carli (Eds.), Historia de la Educación Argentina VI. Discursos pedagógicos e imaginario social en el peronismo (1945-1955) [Argentinian Education History VI. Educational and Social Imaginary Discourses in Peronism (1945-1955)] (pp. 107-176). Buenos Aires: Editorial Galerna.

Fiorucci, F. (2014). Maestros para el sistema de educación pública. La fundación de escuelas normales en Argentina (1890-1930) [Teachers for the Public School System. The Foundation of Normal Schools in Argentina (1890-1930)]. Revista Mexicana de Historia de la Educación [Mexican Journal on History of Education], 2, 25-45.

Foucault, M. (1979). La Arqueología del saber [The Archaeology of Knowledge]. México: Siglo XXI.

Gómez Campo, V. M., \& Tenti Fanfani, E. (1989). Universidad y profesiones. Crisis y alternativas [University and Professions. Crisis and Alternatives]. Buenos Aires: Miño y Dávila.

Gramsci, A. (1975). El materialismo histórico y la filosofía de Benedetto Croce [Historical Materialism and the Philosophy of Benedetto Croce]. México: Juan Pablos Editor.

Kant, I. (2004). El conflicto de las facultades [The Conflict of the Faculties]. Buenos Aires: Losada.

Kisilevsky, M. (1999). Estudiantes de Formación Docente, Universitarios y Maestros: Perfiles y Circuitos [Students of Teacher Training, University and Teachers: Profiles and Circuits]. Buenos Aires: Mimeo.

Kisilevsky, M., \& Velada, C. (2002). Dos estudios sobre el acceso a la Educación Superior en la Argentina [Two Studies on Access to Higher Education in Argentina]. Buenos Aires: IIPE-UNESCO.

Krotsch, P. (1995). La emergencia del estado evaluador: El sistema universitario argentino y el surgimiento de la institución [The Emergence of the Evaluative State: The Argentine University System and the Emergence of the Institution]. In J. E. Esquivel Larrondo (Ed.), La Universidad hoy y mañana [The University Today and Tomorrow] (pp. 64-80). México: CESU-ANUIES.

Krotsch, P., \& Suasnábar, C. (2002). Los estudios sobre la Educación Superior: Una reflexión en torno a la existencia y posibilidades de construcción de un campo [Research on Higher Education: A Reflection on the Existence and Possibilities of Constructing a Field]. Revista Pensamiento Universitario [University Thoughts Journal], 10, 35-54.

Marginson, S., \& Mollis, M. (2001). The Door Opens and the Tiger Leaps. Theories and Reflexivities of Comparative Education for a Global Millennium. Comparative Education Review, 45, 581-615. http://dx.doi.org/10.1086/447693

Merlo, A. (2007). Trayectorias y contexto institucional de la formación docente [Trajectories and Institutional Context of Teacher Education]. In La problemática de la formación docente. I Jornadas Nacionales de Investigación Educativa, II Jornadas Regionales, IV Jornadas Institucionales [The Issue of Teacher Training. I National Conference on Educational Research, Regional Conference II, IV Institutional Days]. Mendoza: Universidad Nacional de Cuyo. http://www.feeye.uncu.edu.ar/web/posjornadasinve/area4/Capacitacion\%20-\%20perfeccionamiento\%20-\%20profesionaliz acion/area4-1.htm

Mollis, M. (2001). La universidad argentina en tránsito. Ensayos para jóvenes y no tan jóvenes [The Argentina University in Transition. Essays for Young and Not So Young]. Buenos Aires: FCE.

Mollis, M. (2008). Las reformas de la educación superior para el Nuevo Milenio [The Reforms of Higher Education for the 
New Millennium]. Revista da Avaliação da Educação Superior [Reviewed Journal of Higher Education Evaluation], 13, 509-532. http://dx.doi.org/10.1590/S1414-40772008000200012

Naishtat, F., Toer, M., \& Aronson, P. (2005). Democracia y representación en la universidad: El caso de la UBA desde la visión de sus protagonistas [Democracy and Representation at the University: The Case of the UBA-University of Buenos Aires-From the Perspective of Its Protagonists]. Buenos Aires: Biblios.

Nowotny, H., Scott, P., \& Gibbons, M. (2002). Re-Thinking Science. Malden: Blackwell Publishers.

Nun, J. (2001). Democracia. Gobierno del pueblo o gobierno de los políticos? [Democracy. Government of the People or Government of the Politicians?]. Buenos Aires: Fondo de Cultura Económica.

Ozslak, O. (1997). La formación de Estado Argentino [The Formation of the Argentine State]. Buenos Aires: Planeta.

Pulfer, D. (1993). Sistema Educativo Nacional de Argentina [Argentinian National Educational System]. Madrid: Ministry of Education and Science of Spain and Organization of Ibero-American States (OEI). http://www.oei.es/quipu/argentina/index.html\#sis2

Sader, E., Gentili, P., \& Aboites, H. (Eds.) (2008). La reforma universitaria: Desafíos y perspectivas noventa años después [The University Reform: Challenges and Prospects Ninety Years Later]. Buenos Aires: Consejo Latinoamericano de Ciencias Sociales-CLACSO.

Salgado Peña, R. U. (2006). La formación docente en la región: De las normales a las universidades [Teacher Training in the Región: From Normal Schools to Universities]. In IESALC-UNESCO (Ed.), Informe sobre la educación superior en América Latina y el Caribe 2000-2005 [Reporton Higher Education in Latin America and the Caribbean 2000-2005] (pp. 171-182). Caracas: Instituto Internacional de la UNESCO para la Educación Superior de América Latina y el Caribe.

Southwell, M., \& De Luca, R. (2008). La descentralización antes de la descentralización: Políticas educativas durante el gobierno de Onganía [Decentralization before Decentralization: Education Policy under Onganía’s Government]. In R. Laborde (Ed.), Revista de la Escuela Ciencias de la Educación [Education Sciences School Review] (pp. 375-389). Rosario: Facultad de Humanidades y Artes, Universidad Nacional de Rosario.

Tedesco, J. C. (1977). Industrialización y educación en la Argentina [Industrialization and Education in Argentina]. Buenos Aires: PNUD-DEALC/1.

Tedesco, J. C. (1985). Reflexiones sobre la universidad argentina [Considerations about the Argentinian University]. Punto de Vista. Revista de Cultura [Point of View. Culture Jorunal], 7, 32-34.

Tenti Fanfani, E. (Coord.) (2010). Estudiantes y profesores de la formación docente. Opiniones, valoraciones y expectativas [Students and Teachers of Teacher Training. Opinions, Evaluations and Expectations]. Buenos Aires: Ministerio de Educación de la Nación.

Vidal, G. (2005). La Reforma Universitaria de 1918 y la Unión Cívica Radical [The University Reform of 1918 and the Radical Civic Union]. In Cuadernos de Historia, Serie Economía y Sociedad [Notes of History. Economy and Society Series] ( No. 7, pp. 187-212). Córdoba: CIFF y H-UNC.

Weinberg, D. (1967). La enseñanza técnica industrial en la Argentina 1936-1965 [Industrial Technical Education in Argentina 1936-1965]. Buenos Aires: ITDT.

Wiñar, D. (1970). Poder político y educación. El peronismo y la Comisión Nacional de Aprendizaje y Orientación Profesional [Political Power and Education. Peronism and the National Learning and Vocational Guidance]. Buenos Aires: ITDT. 


\section{Laws, Documents and Maps}

Anuario de Estadísticas Universitarias 2011. Secretaría de Políticas Universitarias, Ministerio de Educación de la Nación [University Statistics Yearbook 2011. Secretariat of University Policies, Ministry of National Education].

Censo de la Universidad de Buenos Aires 2011 [Census of theUniversity of Buenos Aires 2011].

Censo Nacional de Docentes del 2004 [National Census of Teachers 2004].

Constitución Nacional del Estado Argentino, 1994 [Constitution of the Argentine State, 1994].

Decreto-Ley de Universidades Nacionales, Decreto-Ley 6403, 1955 [Decree-Law of National Universities, Decree Law 6403, 1955].

Ley de Centros de Estudiantes, Ley N²6.877, 2013 [Law of Student Unions, Law No. 26,877, 2013].

Ley de Educación Común, Ley N¹420, 1884 [Common Education Law, Law No. 1420, 1884].

Ley de Educación Nacional (LEN), Ley N²6.206, 2006 [National Education Act (LEN) Law No. 26,206, 2006].

Ley de Educación Superior, Ley N²4.521, 1995 [Higher Education Act, Law No. 24,521, 1995].

Ley de Educación Técnico-Profesional, Ley N²6.058, 2005 [Law of Technical-Profesional Education, Law No. 26,058, 2005].

Ley de Estatutos de las Universidades Nacionales (Ley Avellaneda), Ley N¹597, 1885 [Law Statutes of the National Universities (Avellaneda's Law), Law No. 1597, 1885].

Ley de Transferencia de Establecimientos Educativos, Ley N ${ }^{\circ} 24.049,1992$ [Transfer Act Educational Establishments, Law No. 24,049, 1992].

Ley Federal de Educación, Ley N²4.195, 1993 [Federal Education Law, Law No. 24,195, 1993].

Ley Guardo, Ley N¹3.031, 1947 [Guardo’s Law No. 13,031 Act, 1947].

Ley universidad Nacional de las Artes, Ley N²6.997, 2014 [National University of Arts’ Act, Law No. 26,997, 2014]. 